\title{
The Holy Spirit as feminine: Early Christian testimonies and their interpretation
}

\begin{tabular}{|c|c|}
\hline $\begin{array}{l}\text { Author: } \\
\text { Johannes van }\end{array}$ & Dort $^{1,2}$ \\
\hline $\begin{array}{l}\text { Affiliations: } \\
{ }^{1} \text { Radboud Uni } \\
\text { Nijmegen, The }\end{array}$ & $\begin{array}{l}\text { ersity, } \\
\text { Netherlands }\end{array}$ \\
\hline $\begin{array}{l}{ }^{2} \text { Department } \\
\text { History and Ch } \\
\text { Faculty of The } \\
\text { of Pretoria, So }\end{array}$ & $\begin{array}{l}\text { f Church } \\
\text { urch Polity, } \\
\text { logy, University } \\
\text { th Africa }\end{array}$ \\
\hline $\begin{array}{l}\text { Project leader } \\
\text { Project numb }\end{array}$ & $\begin{array}{l}\text { J. van Oort } \\
\text { r: } 02596857\end{array}$ \\
\hline $\begin{array}{l}\text { Description: } \\
\text { This research } \\
\text { project, 'Augu } \\
\text { Manichaean } \\
\text { directed by Pr } \\
\text { van Oort, Prof } \\
\text { Extraordinariu } \\
\text { of Church Hist } \\
\text { Polity, Faculty } \\
\text { University of P }\end{array}$ & $\begin{array}{l}\text { s part of the } \\
\text { tine and } \\
\text { hristianity', } \\
\text { of. Dr Johannes } \\
\text { essor } \\
\text { s, Department } \\
\text { ory and Church } \\
\text { of Theology, } \\
\text { retoria. }\end{array}$ \\
\hline $\begin{array}{l}\text { Correspondin } \\
\text { Johannes van } \\
\text { j.van.oort@pl }\end{array}$ & $\begin{array}{l}\text { author: } \\
\text { Jort, } \\
\text { inet.nl }\end{array}$ \\
\hline $\begin{array}{l}\text { Dates: } \\
\text { Received: } 22 \\
\text { Accepted: } 02 \\
\text { Published: } 19\end{array}$ & $\begin{array}{l}\text { ct. } 2015 \\
\text { eb. } 2016 \\
\text { Aug. } 2016\end{array}$ \\
\hline $\begin{array}{l}\text { How to cite th } \\
\text { Van Oort J., } 20 \\
\text { Spirit as femin } \\
\text { Christian testi } \\
\text { their interpret } \\
\text { HTS Teologies } \\
\text { Theological St } \\
\text { a3225. http:// } \\
\text { 10.4102/hts.v }\end{array}$ & $\begin{array}{l}\text { is article: } \\
16, \text { 'The Holy } \\
\text { ine: early } \\
\text { nonies and } \\
\text { ation', } \\
\text { Studies/ } \\
\text { ıdies } 72(1), \\
\text { dx.doi.org/ } \\
2 \text { i1.3225 }\end{array}$ \\
\hline $\begin{array}{l}\text { Copyright: } \\
\text { (C) 2016. The A } \\
\text { Licensee: AOS } \\
\text { is licensed unc } \\
\text { Creative Comr } \\
\text { Attribution Lic }\end{array}$ & $\begin{array}{l}\text { uthors. } \\
\text { S. This work } \\
\text { ler the } \\
\text { lons } \\
\text { ense. }\end{array}$ \\
\hline Read online: & \\
\hline 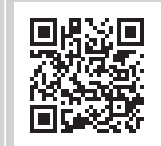 & $\begin{array}{l}\text { Scan this QR } \\
\text { code with your } \\
\text { smart phone or } \\
\text { mobile device } \\
\text { to read online. }\end{array}$ \\
\hline
\end{tabular}

The earliest Christians - all of whom were Jews - spoke of the Holy Spirit as a feminine figure. The present article discusses the main proof texts, ranging from the 'Gospel according to the Hebrews' to a number of testimonies from the second century. The ancient tradition was, in particular, kept alive in East and West Syria, up to and including the fourth century Makarios and/or Symeon, who even influenced 'modern' Protestants such as John Wesley and the Moravian leader Count von Zinzendorf. It is concluded that, in the image of the Holy Spirit as woman and mother, one may attain a better appreciation of the fullness of the Divine.

\section{Introduction}

In two previous articles, I discussed the place and role of both the doctrine and the experience of the Holy Spirit in the Early Church (Van Oort 2011;2012). An important aspect remained, however: namely the fact that many early Christian authors - in particular those belonging to so-called 'Jewish Christianity' ${ }^{1}$ - spoke of the Holy Spirit as Mother.

How did this come to pass? And which consequences may be derived from this phenomenon for present-day discourse on the Holy Spirit?

An essential background to the occurrence of the Holy Spirit as Mother is, of course, the fact that the Hebrew word for Spirit, ruach, is in nearly all cases feminine. The first Christians, all of whom were Jews, took this over. Also in Aramaic the word for Spirit, rucha, is feminine. All this, however, does not fully account for the early Jewish Christian practice. A close reading of the relevant texts will reveal more.

\section{Jewish Christian sources}

\section{Origen and the 'Gospel according to the Hebrews'}

The first prooftext, which already brings in medias res, is from the Greek church father Origen (c. 185-254). In his Commentary on the Gospel of John, he says:

If anyone should lend credence to the Gospel according to the Hebrews, where the Saviour Himself says, 'My Mother (mêtêr), the Holy Spirit, took me just now by one of my hairs and carried me off to the great Mount Tabor', he will have to face the difficulty of explaining how the Holy Spirit can be the Mother (mêter $)$ of Christ when She was herself brought into existence through the Word. But neither the passage nor this difficulty is hard to explain. For if he who does the will of the Father in heaven [Mt. 12:50] is Christ's brother and sister and mother (mêtêr), and if the name of brother of Christ may be applied, not only to the race of men, but to beings of diviner rank than they, then there is nothing absurd in the Holy Spirit's being His Mother (mêter r); everyone being His mother who does the will of the Father in heaven. (Origen, Commentary on the Gospel of John 2, 12 - Preuschen 1903:67)

Origen, who in all probability dictated these lines when he was in Palestinian Caesarea, refers to a 'Gospel according to the Hebrews'. Until today there is much discussion about the origin and contents of this Gospel (e.g. Frey 2012:593-606; Luomanen 2012:1-2, 235-243), but all specialists agree that it was of Jewish Christian provenance. Apart from several other things, we learn from this quote that, sometime in the beginning of the second century $\mathrm{CE}$, the Jewish Christians of this Gospel spoke of the Holy Spirit as Mother (mèter $)$.

The same is evident in another quote from Origen:

... but if one accepts (the following): 'My Mother (mêtêr ), the Holy Spirit, took me just now and carried me off to the great Mount Tabor,' one could see who is his Mother (mêtêr). (Origen, Homilies on Jeremiah 15, 4 - Klostermann 1901:128)

1.The term 'Jewish Christianity" is used here to denote those ancient form(s) of Christianity which directly stemmed from Jews and retained typical features of their faith and ways of thinking. 
From both quotes we may also learn that Origen himself accepted the concept of the Holy Spirit as Mother.

\section{Jerome and the 'Gospel according to the Hebrews'}

The church father Jerome (c. 342-420), who spent many years in Bethlehem, makes mention of several passages from the Gospel of the Hebrews, too. In his Commentary on Micah, he says:

... and he should believe in the Gospel, which has been edited according to the Hebrews, which we have translated recently, in which it is said of the person of the Saviour: 'My Mother (mater), the Holy Spirit, took me just now by one of my hairs ....' (Jerome, Commentary on Micah 2, 7, 6 - Adriaen 1969:513)

The essence of the same quote from the Gospel of the Hebrews is found in Jerome's Commentary on Ezekiel:

\begin{abstract}
... and this relates to the Holy Spirit, who is mentioned with a female name (nomine feminino) among the Hebrews. For also in the Gospel which is of the Hebrews and is read by the Nazaraeans, the Saviour is introduced saying: 'Just now, my Mother (mater), the Holy Spirit, took me up ...' (Jerome, Commentary on Ezekiel 4, 16, 13 - Glorie 1964:178).
\end{abstract}

In his Commentary on Isaiah, Jerome states:

And also this: (in the text) 'like the eyes of a maid look to the hand of her mistress' [Ps. 123:2], the maid is the soul and the mistress (dominam) is the Holy Spirit. For also in that Gospel written according to the Hebrews, which the Nazaraeans read, the Lord says: 'Just now, my Mother (mater), the Holy Spirit, took me.' Nobody should be offended by this, for among the Hebrews the Spirit is said to be of the feminine gender (genere feminino), although in our language it is called to be of masculine gender and in the Greek language neuter. (Jerome, Commentary on Isaiah 11, 40, 9 - Adriaen 1963:459)

While Jerome was well acquainted with the old Jewish Christian tradition of the femininity of the Holy Spirit, which in his time was still alive among the 'Nazaraeans', who read the 'Gospel according to the Hebrews', he considered it to be a question of language only.

\section{Epiphanius and Hippolytus on the prophet Elxai}

For the Jewish Christians themselves, however, it was not merely a question of language. Apart from the Gospel according to the Hebrews, this is testified by a number of testimonies regarding the prophet Elxai. This Jewish Christian prophet-in the various sources also named as Elchasai, Alchasaios, Elkesai and Elxaios-is said to have received the revelation written about in the Book of Elchasai in Mesopotamia in the year 116-117.

The church father Epiphanius (c. 315-430), for many years bishop of Salamis and the metropolitan of Cyprus, transmits this revelation as follows:

Next he describes Christ as a kind of power and also gives His dimensions (...)And the Holy Spirit is (said to be) like Christ, too, but She is a female being (thēleian) (...). (Epiphanius, Panarion 19, 4, 1-2 - Holl I, 1915:219)
Later on in his book, Epiphanius reports essentially the same:

And he [i.e., Elxai] supposed also that the Holy Spirit stands over against Him (i.e., Christ) in the shape of a female being (en eidei thēleian) (...). (Epiphanius, Panarion 30, 17, 6 - Holl I, 1915:375)

Earlier the learned Hippolytus (c. 170-c. 236), a Christian presbyter at Rome, had transmitted the same tradition on Elchasai:

There should also be a female (theleian) with Him (i.e., with Christ as an angel) (...) The male is the Son of God and the female (thēleian) is called the Holy Spirit. (Hippolytus, Refutatio 9, 13, 3 - Wendland 1916:251)

\section{The Pseudo-Clementines}

A next testimony to the Holy Spirit's femininity may be derived from the so-called Pseudo-Clementines. The PseudoClementines is a work circulated under the name of Clement of Rome (fl. c. 96), which came down to us in two fourthcentury forms: the Greek Homilies and the Latin Recognitions. Both forms contain very old Jewish Christian source material. The Jewish Christian concept of the Spirit as a feminine Being is, by implication, preserved in one of the Homilies:

And Peter answered: 'One is He who said to His Wisdom, 'Let us make a man' [Gen. 1:26]. His Wisdom (sophia), with Her (Greek: hei, 3rd p. sing. feminine) He Himself always rejoiced [Prov. 8:30] just as (hōsper) with His own Spirit (pneumati).' (Ps.-Clementines, Hom. 16, 12, 1 - Rehm 1969:223)

The text identifies Wisdom with the Holy Spirit. This equation of Wisdom (chokma, sophia) and Holy Spirit (ruach, pneuma) has old parallels in Jewish and Jewish Christian traditions. Already in the Jewish book Wisdom of Solomon, preserved in Greek as part of the Septuagint and being in high esteem among most early Christian writers, one finds this equation; for instance, in Wisdom 9, 17 it runs:

Who has learned thy (i.e., God's) counsel, unless thou hast given wisdom (sophian) and sent thy holy Spirit (pneuma) from on high? (Wisdom of Solomon 9, 17 [Revised Standard Version])

Wisdom is equated with the Holy Spirit and both are considered to be feminine. ${ }^{2}$ Hence one understands how in early Christian tradition Christ is so often considered to be the child of mother Sophia or the Holy Spirit. ${ }^{3}$ In essence, both traditions express the same concept. The oldest patristic testimonies to this concept are the texts from Origen and Jerome quoted above.

In interpreting all these testimonies, one should bear in mind that ancient Jewish Christianity did not express itself in Greek discursive terminology, but in Semitic metaphorical language. Or, stated otherwise: the Jewish Christians expressed themselves in images, not in logical concepts. Accordingly, one may also understand that the Christian concept of Trinity is not merely due to Greek philosophical thinking, 2.For this and related Jewish texts, see e.g. Bousset and Gressmann $(1966: 346,397)$. 3.One of the first who saw this was Schüssler Fiorenza (1983:132-135); one may compare, for instance, Barker: 1992:48-69 [= Ch. Four: 'The Evidence of Wisdom']). compare, for instance, Barker: 1992:48-69 [ $[=$ Ch. Four: 'The Evidence of Wisdom']).
Sometimes, however, their reasoning and rather quick conclusions should be taken Sometimes, how
with caution. 
but has genuine and extremely old sources in Jewish Christian writings. ${ }^{4}$ One may reread the statements of Hippolytus and Epiphanius on Elxai's vision of God with his Son and the female Spirit as quoted above.

\section{Theophilus and Irenaeus}

The influence of the archaic Jewish Christian tradition on Spirit and Sophia is even found in Greek Christian authors such as Theophilus of Antioch (fl. later 2nd c.) and Irenaeus of Lyon (c. 130-c. 200). In his writing Against Autolycus, the Greek bishop and apologist Theophilus wrote for instance:

God made everything through His Logos and Sophia, for 'by His Logos the heavens were made firm and by His Spirit all their power.' [Ps.32:6] (...)

Similarly the three days prior to the luminaries [cf. Gn. 1] are types of the Triad (triados), of God and His Word and His Wisdom (Theophilus, Ad Autol. 1, 7; 2, 15 - Grant 1970:10; 52).

In Greek speaking bishop Irenaeus' work Against Heresies, which is mainly transmitted in Latin, it runs inter alia:

\footnotetext{
... the Son and the Holy Spirit (Spiritus), the Word and the Wisdom (Sapientia) (...)
}

For with Him were always present the Word and the Wisdom (Sapientia), the Son and the Spirit (Spiritus)

Irenaeus, Adv. Haer. 4, 7, 4; 20, 1. (Rousseau 1965:464; 626)

\section{The Pastor of Hermas}

The Shepherd of Hermas is a rather enigmatic and, in all probability, composed document which originated in Rome between the end of the first and the middle of the second century. Its final form consists of five 'Visions', twelve 'Mandates' and ten 'Similitudes'. In the second and third centuries, it was accepted as Scripture by several ecclesiastical authors and even Didymus the Blind, a contemporary of Athanasius in the fourth century, included it in his canon of Scripture. It is also found in the highly important biblical manuscript Codex Sinaiticus, dating from the same time..$^{5}$ In many of its utterances, the Shepherd reveals its Jewish Christian provenance.

One of these Jewish Christian features is the concept of the Holy Spirit as feminine. Although the Shepherd of Hermas (now generally classified as one of the 'Apostolic Fathers') uses the word 'spirit' in a variety of ways, in several cases 'spirit' appears to mean 'Holy Spirit'. One of these cases is Similitude IX (Körtner \& Leutzsch 1998:300 ff.), where the Holy Spirit is presented in the image of twelve virgins (parthenoi). The plural should not lead us astray here. ${ }^{6}$ Elsewhere in the Shepherd the Holy Spirit-in her equivalent the Church-is described as being pre-existent and also as

4.Kretschmar (1956:99) considers the scheme of Elxai's vision to be "die älteste Form der "Trinitätslehre"' ('the oldest form of the "doctrine of the Trinity"').

5.Unfortunately the end of Codex $\mathrm{x}$ did not survive.

6.With reference to Seeberg (1924:371, 1922:140), his promovenda Selma Hirsch wrote in her dissertation (1926:41), 'Der Geist wird hier pluralisch, als eine Mehrheit von Geistern gedacht, "was aber ebensowenig wie אלזהים oder מדזים usw. auf eine Vielheit von Wesen zu deuten, sondern nur auf die Mannigfaltigkeit der in einem Wesen zusammengefaßten Kräfte hinweist". an old women (gunē presbutis) (Vis. I, 2, 2; cf. e.g. II, 4, 1 ff.: presbutera in Körtner \& Leutzsch 1998:158). ${ }^{7}$

\section{Melito of Sardis}

Some decades later, and in another part of the Roman Empire, Melito of Sardis († c. 190) composed his homily On the Passover. It became famous after its discovery and publication by Campbell Bonner in 1940. In its newest editions one finds some fragments added, the seventeenth of which reads as follows:

Hymn the Father, you holy ones;

sing to your Mother (tēi mètri), virgins.

We hymn, we exalt (them) exceedingly, we holy ones.

You have been exalted to be brides and bridegrooms,

for you have found your bridegroom, Christ.

Drink for wine, brides and bridegrooms ... (Melito, Frg. 17 - Hall 1979:84-85)

It does not seem to be beyond doubt that the fragment, which follows On the Passover in a Bodmer Papyrus Codex, really stems from Melito. In any case it is a liturgical dialogue, if not part from Melito's sermon, then perhaps of a baptismal liturgy. In its main theme and imagery, On the Passover is close to Jewish Christian thinking in general and Jewish Paschal tradition in particular. In the just quoted fragment, the Mother is without a doubt the Holy Spirit.

\section{Sources from East and West Syria}

As we have just seen with Theophilus, Irenaeus, the Pastor Hermae and (perhaps) Melito, the concept of the Spirit as feminine is sometimes found as an archaic reminiscence of Jewish Christianity in later Greek writers. However, in several Christian writings stemming from Syria, which mainly had Syriac (a branch of Aramaic) as their original language, this speaking of the Holy Spirit as feminine really abounds.

\section{The Gospel of Thomas}

Apart from some Greek scraps, the Gospel of Thomas has been mainly transmitted in a Coptic translation found in the second codex of the 'gnostic' library which, in December 1945, was discovered near Nag Hammadi in Upper Egypt. ${ }^{8}$ Many researchers maintain that the Gospel of Thomas - in any case in its original form(s) —was not 'gnostic' at all, nor even tincted with typical 'gnostic' ideas, but a fine example of primitive Jewish and Syrian Christianity. One of its logia reads as follows:

(Jesus said:) Whoever does not hate his father and his mother in My way will not be able to be a (disciple) to me. And whoever does (not) love (his father) and his mother in My way will not be able to be a (disciple) to me, for My mother (tamaay) (...) but (My) true (Mother) gave me the Life. (Gospel of Thomas, logion 101 Guillaumont a.o. 1998:50; Nagel 2014:152)

Here, the true Mother is the Holy Spirit.

7.More on the Shepherd's pneumatology in concise form in e.g., Osiek (1999:31-34).

8.See e.g. Robinson (2014). Here and elsewhere I speak of 'gnostic' (between parentheses) to indicate that, in modern research, the term has become problematic. 


\section{The Acts of Thomas}

The Acts of Thomas recount the missionary activities of the apostle Judas Thomas. It is generally agreed that the composite work, which has survived in several Syriac and Greek manuscripts, was written in Syriac sometime before the middle of the third century. It contains many archaic elements pointing to early Jewish Christian tradition in Syria.

One of these archaic Jewish Christian elements is the concept of the Holy Spirit as feminine. It is clearly found in the following texts transmitted in Greek:

And the apostle arose and sealed them (...): Come, compassionate Mother (mètēr); (...) Come, Mother (mètèr) of the seven houses (...); Come, Holy Spirit (pneuma) and cleanse their loins and their heart, and seal them in the name of the Father and the Son and the Holy Spirit (pneumatos). (Acta Thomae 27 - Lipsius-Bonnet 1903 [repr. 1972]:142-143)

... we praise and glorify You (Christ), and Your invisible Father, and Your Holy Spirit (pneuma), (and) the Mother (mêtera) of all creation. (Acta Thomae 39 - Lipsius-Bonnet 1903 [repr. 1972]:157)

Come, secret Mother (mètēr); Come, You who (fem.) are manifest in your deeds; You who (fem.) gives joy and rest to those who are united to You (fem.). (Acta Thomae 50 - Lipsius-Bonnet 1903 [repr. 1972]:166)

One may also compare Acta Thomae 7 (the Syriac text speaks of the glorification of 'the Father, the Lord of all' and 'the Spirit, His Wisdom') (cf. Klijn 2003:29), whereas the Greek text has: 'The Father of truth and the Mother of Wisdom') and Acta Thomae 133 ('We name over you [i.e. the 'bread of life' in the eucharist] the name of the Mother [= the Holy Spirit]).

\section{Gospels in Old Syriac, the Odes of Solomon, the Didascalia and the Apostolic Constitutions}

A number of other writings from the Syrian world may be briefly dealt with under one heading. The first is the Old Syriac Version of the Gospels, which reaches back to the second century and transmits Jn 14:26 as follows:

... but that (Syr.: $h i=$ she) Spirit, the Paraclete that my Father will send to you in my name, She (Syr. hi) shall teach you everything, She (hi) shall remind you of all what I say. (Evangelium daMepharrese - tr. Burkitt 1904:510-511)

In all probability, the Odes of Solomon are a (Jewish) Christian work which is almost certainly written in Syria or Palestine in the course of the same second century. In Ode 36, 3 it runs:

The Spirit of the Lord rested upon me,

and She lifted me up to the height (...)

She brought me forth before the face of the Lord (...)

For according to the greatness of the Most High,

so She made me (...) (Odes of Solomon 36, 3a - tr. Lattke 2009:492)

The Didascalia Apostolorum ('Teaching of the Apostles') is an ancient 'Church Order' which seems to have been composed in Syria in the earlier half of the third century. In the Syriac text of chapter 11 it runs:

This (i.e., the bishop) is your chief and your leader, and he is your mighty king. He rules in the place of the Almighty: but let him be honoured by you as God (...). But the deacon stands in the place of Christ, and do you love him. And the deaconess shall be honoured by you in the place of the Holy Spirit (...). (Didascalia apostolorum 9 -tr. Connolly 1929:86-88)

Virtually the same is stated in the Apostolic Constitutions, a collection of ecclesiastical commandments dating from the latter half of the fourth century and almost certainly of Syrian provenance:

Let also the deaconess (diakonis) be honoured by you in the place of the Holy Spirit (eis typon tou hagiou pneumatos) (...) (Apostolic Constitutions II, 26, 6 - Funk 1905:296)

\section{Aphrahat and Ephrem}

Clear resonances of this kind of representation are present in Aphrahat. As a rule he is said to be the first of the (orthodox) Syriac church fathers and also 'the Persian sage'. We mainly know him from his so-called 'Demonstrations', a work dating from about 340. In the eighteenth Demonstration it runs with reference to Genesis 2:24:

Who is it that leaves father and mother to take a wife? The meaning is this. As long as a man has not taken a wife he loves and reveres God his Father and the Holy Spirit his Mother, and he has no other love. (Aphrahat, Dem. 18 - Parisot 1980:840; tr. Murray 1975:143)

One may add to this quote a passage from Demonstration VI, where Aphrahat speaks of the role of the Spirit in baptism:

From baptism we receive the Spirit of Christ, and in the same hour that the priests invoke the Spirit, She opens the heavens and descends, and hovers over the waters [cf. Gen. 1:2], and those who are baptized put Her on. (Aphrahat, Dem. 6 - Parisot 1980:292-293; tr. Murray 1975:143)

Although Ephrem Syrus (c. 306-373), who wrote most of his extant works in Edessa, conjugates the Syriac word rucha as feminine, one finds only one or two passages ${ }^{9}$ in his œuvre which highlight her femininity. In one of these it runs:

It is not said of Eve that she was Adam's sister or his daughter, but that she came from him; likewise it is not to be said that the Spirit is a daughter or sister, but that (She) is from God and consubstantial with Him. (Ephrem, Commentary on the Concordant Gospel or Diatessaron 19, 15 - Leloir 1953:277; tr. Murray 1975:318)

\section{Makarios/Symeon}

Finally, an extremely rich and influential source is constituted by the homilies of Symeon of Mesopotamia. For centuries, these homilies were transmitted under the name of Makarios (Macarius), an Egyptian monk who lived c. 300-390 and was a staunch supporter of Athanasius. Modern research, however, established that their real author is no other than a certain contemporary Symeon, who lived in Mesopotamia, in the vicinity of the upper Euphrates. The homilies of

9.Cf. Murray (1975:318-319, 144 n. 2): ‘... two passages in the Diatessaron commentary suggest that he was familiar with the tradition'. With reference to commentary suggest that he was familiar with the tradition'. With reference to
Murray (1975:313-319), Chorbishop Seely Joseph Beggiani (2014:81), reduces this to one. 
this Symeon mainly survive in Greek in four collections. The second collection, consisting of fifty 'spiritual' homilies, became the most popular, but the other three are important as well. ${ }^{10}$

Here I quote only some of the most conspicuous examples, derived from a number of editions of the various collections. In the most influential Fifty Homilies, we read:

And from his (sc. Adam's) time until the last Adam, the Lord, man did not see the true heavenly Father and the good and kind Mother (mêtera), the grace of the Spirit (pneumatos) (...). (Makarios/Symeon, Hom. 28, 4 - Dörries, Klostermann \& Kroeger 1964:232-233)

Elsewhere it runs of the Holy Spirit:

She (autē) is the kind and heavenly Mother (mèter) (...) (Makarios/ Symeon, Hom. 27, 4 - Klostermann 1961:155)

Repeatedly it is stressed by Makarios that there is no human birth without a mother, and therefore no spiritual birth without the Holy Spirit (e.g. Hom. 8, 1; Klostermann 1961:37). As the mother (mèter) of young birds cares for them, so the Holy Spirit provides food for God's children (Hom. 16, 2; Klostermann 1961:79-81). At another occasion, Makarios speaks of 'the grace of the Spirit, the Mother (mêter) of the holy' (Hom. 27, 1; Klostermann 1961:151).

Over the centuries, the writings of Makarios and/or Symeon have exerted an enormous influence, both in the East and in the West, not only in Syriac Christianity and other Eastern Orthodox circles, but also among Protestants. It is interesting to note that, among many others (see e.g. Benz 1963; Van de Bank 1977), both the very influential John Wesley ${ }^{11}$ and the also very influential Nikolaus Ludwig Graf von Zinzendorf were deeply influenced by Makarios. Although in the case of the first one I was not able to find any stress on the femininity of the Holy Spirit, in Zinzendorf there is indeed. In his first address in Pennsylvania, for instance, he said that 'the Father of our Lord Jesus Christ is our true Father, and the Spirit of Jesus Christ is our true Mother'. ${ }^{12}$

\section{Conclusions}

Here I may conclude. It is not my aim to further look for influences of early Christian testimonies in this respect, nor did I even intend to be complete in my overview of early Christian texts. ${ }^{13}$ I only tried to make clear a certain current, which had its initials in early Jewish Christianity

\footnotetext{
10.Further particulars on the diverse (and overlapping) collections conveniently in, for instance Drobner (2007:370-372).

11.See e.g. Outler (1964 [paperback ed. 1980]: 9 where Outler also mentions his particular interest in Ephrem Syrus). Cf. e.g. a quote from Wesley himself ('A plain account of genuine Christianity') on p. 195. More on Wesley's study of Makarios and the translation of his works in Benz (1963:118-127, n. 14).

12.Beyreuther \& Meyer (1963:38): ' '.. da der Vater unsers Herrn Jesu Christi unser wahrhaftiger Vater/ und der Geist Jesu Christi unsere wahrhaftige Mutter ist (...)'. A little further on it runs (38): ' daß es nicht anders sein A little further on it runs (38): ' ... daß es nicht anders sein kann, als daß sein $=$ Christ's) Vater auch unser Vater und seine Mutter auch unsere Mutter sein muß' and near the end (45): .... so spricht man von seinem und unserm Vater/ von dem Geist, der seine und unser aller wahrhafftige Mutter ist ...'

13.An important testimony seems to be Apoc. 12; see e.g. Quispel (2008:749-752).
}

and also exerted its influence on other ('orthodox') Christian writers. It seems to have been the same Jewish and/or Jewish Christian influences which, moreover, can be found in many 'gnostic' texts, but I deliberately excluded these texts from my exposition. ${ }^{14}$ Here I just note that sometimes genuine Christian traditions and concepts, which became forgotten in mainstream Christendom, were kept alive in 'heretical' Christian circles.

It would be completely wrong to state that the image of the Holy Spirit as a woman and mother is simply caused by the fact that the Hebrew, Aramaic and Syriac words for 'spirit' are (nearly) always feminine. Of course this was an important factor, but there were other significant factors as well, such as the link between the figures of the Holy Spirit and Wisdom or between Holy Spirit and the Jewish feminine concept of the Divine Presence or Shekinah. ${ }^{15}$ Moreover, it should be remarked that, still, we are dealing with metaphorical language. Religious language is inherently metaphorical, that is, bound to images and similes. By its very nature it cannot define God's essence. All ancients were aware of the fact that this essence of the Divine remains a holy mystery and is by nature ineffable.

Nevertheless, the very first Christians, all of whom were Jews by birth, used to speak of the Holy Spirit as feminine. These Jewish Christians (or, perhaps better: Christian Jews) adhered to Genesis 1:27 where it is said that God created male and female after his image. If this text is really taken for true, then something female is inherent to God. Apart from the image of a Mother, Syrian and other Jewish Christians stressed the 'hovering' (rahhef) of the Spirit as stated, for instance, in Genesis 1:2 and Deuteronomy 32:11. ${ }^{16}$ Besides, they attributed to the Spirit the motherly features which Jewish prophetic writings like Isaiah (49:15-15; 66:13) find in God. One may also bring to mind that, according to Matthew, Jesus compared himself to a mother bird (Mt. 23:37). Moreover, when believers are born anew from the Spirit (e.g. Jn 3), they are 'children of the Spirit', who is their 'Mother'. ${ }^{17}$

An expression such as 'children of the Spirit' is typical to Makarios..$^{18}$ It explicitly refers to the motherly function of the Holy Spirit. There appears to be a tender aspect in God (see e.g. Is 66:13) which can only be expressed in the simile of the Mother. This does not mean that in this way we have 'defined' God; it just means that in this way we attain a better appreciation of the fullness of the Divine.

\footnotetext{
14.I only mention here Nag Hammadi writings such as the Apocryphon of John (e.g. 10, 17-18: ' $\ldots$ the Holy Spirit, who is called the Mother of the living') and the Gospel of Philip (e.g. 55 and 59), and testimonies such as Irenaeus, Adv. Haer. I, 30 1-2 (the Sethians called the Spirit the First Woman: Primam Feminam) and Epiphanius, Panarion 21, 2, 3 (Simon Magus called Helena the Holy Spirit).

15.I do not enter the difficult question of whether or not Shekinah may be considered as (nearly) identical with God's Spirit. See e.g. Schäfer (2002 [paperback 2004]). It is interesting to read on e.g. pp. 86-91 his argument that the Shekinah (which in his view is not identical to the Spirit) is the female aspect of God.

16.See e.g. Murray (1975:22, 144 and 313, among others).

17.Cf. Murray (1975: e.g. 312ff.)
}

18.See e.g. his Fifty Homilies, e.g. Hom. 16, 8 (Dörries 1964:163) and 30, 2 (Dörries 1964:241). As a matter of fact, he more often speaks of 'Children of God'. 


\section{Acknowledgements Competing interests}

The author declares that he has no financial or personal relationships which may have inappropriately influenced him in writing this article.

\section{References}

Acta Thomae, 1903 [repr. 1972], '27', in R.A. Lipsius \& M. Bonnet (eds.), Acto Apostolorum Apocrypha, II, 2, pp. 142-143, Hinrichs, Leipzig, (repr. Hildesheim Olms).

Acta Thomae, 1903 [repr. 1972], '39', in R.A. Lipsius \& M. Bonnet, (eds.), Acto Apostolorum Apocrypha, II, 2, p. 157, Hinrichs, Leipzig, (repr. Hildesheim, Olms).

Acta Thomae, 1903 [repr. 1972], '50', in R.A. Lipsius \& M. Bonnet (eds.), Acto Apostolorum Apocrypha, II, 2, p. 166, Hinrichs, Leipzig, (repr. Hildesheim, Olms).

Acta Thomae, 2003, '7', in A.F.J. Klijn, (ed.), The Acts of Thomas: Introduction, text, and commentary, p. 29, 2nd rev. edn., Leiden-Boston, Brill.

Aphrahat, 1980, 'Demonstration 6', in J. Parisot (ed.), Aphraatis sapientis Persae Demonstrationes, Patrologia Syriaca, I, 1, p. 143, Firmin-Didot, Paris, (repr. Turnhout: Brepols 1980)

Aphrahat, 1980, 'Demonstration 18', in J. Parisot (ed.), Aphraatis sapientis Persae Demonstrationes, Patrologia Syriaca, I, 1, p. 143, Firmin-Didot, Paris, (repr. Demonstrationes, Patrol
Turnhout: Brepols 1980).

Barker, M., 1992, The Great Angel: A study of Israel's second god, SPCK, London.

Chorbishop, S.J.B., 2014, Early Syriac theology with special reference to the Maronite tradition, rev. ed., The Catholic University of America Press, Washington, DC

Benz, E., 1963, Die protestantische Thebais: Zur Nachwirkung Makarios des Ägypters im Protestantismus des 17. und 18. Jahrhunderts in Europa und Amerika Akademie der Wissenschaften Mainz, Wiesbaden.

Beyreuther, E. \& Meyer, G. (eds.), 1963, Nikolaus Ludwig von Zinzendorf, Hauptschriften, vol. 2, Reden in und von Amerika, Olms, Hildesheim.

Bousset, W. \& Gressmann, H., 1966, Die Religion des Judentums im späthellenistischen Zeitalter, Mohr, Tübingen.

Didascalia Apostolorum, 1929, '9', in R.H. Connolly (ed.), Didascalia apostolorum: The Syriac Version translated and accompanied by the Verona Latin Fragments, pp. 86-88, Clarendon Press, Oxford.

Didascalia et Constitutiones Apostolorum, 1905, 'II, 26, 6', in F.X. Funk (ed.), Didascalia et Constitutiones Apostolorum, p. 296, I, F. Schoeningh, Paderborn.

Drobner, H.R., 2007, The Fathers of the Church: A comprehensive introduction, Hendrickson, Peabody.

Evangelium da-Mepharrese, 1904, Evangelium da-Mepharrese: the Curetonian Version of the four gospels, with the readings of the Sinai palimpsest and the early Syriac patristic evidence edited, collected and arranged by F.C. Burkitt, pp. 510Syriac patristic evidence edited, colle
511, University Press, Cambridge.

Ephrem Syrus, 1953, 'Commentary on the concordant gospel or Diatessaron 19, 15', in L. Leloir (ed.), S. Éphrem, Commentaire de l'Évangile concordant, version arménienne, p. 277, Corpus Scriptorum Christianorum Orientalium 137, Peeters, Leuven.

Epiphanius, 1915, 'Panarion 19, 4, 1-2', in K. Holl (ed.), Epiphanius I, Ancoratus. Panarion (haereses 1-33), p. 219, Hinrichs, Leipzig.

Epiphanius, 1915, 'Panarion 30, 17, 6', in K. Holl (ed.), Epiphanius I, Ancoratus. Panarion (haereses 1-33), p. 375, Hinrichs, Leipzig.

Frey, H., 2012, 'Die Fragmente des Hebräerevangeliums', in Chr. Markschies \& J. Schröter (eds.), Antike christliche Apokryphen in deutscher Übersetzung, vol. 1 pp. 593-606, Evangelien und Verwandtes, Mohr Siebeck, Tübingen.

Hieronymus, 1963, 'Commentary on Isaiah', in M. Adriaen (ed.), Hieronym Commentariorum in Esaiam, p. 459, Corpus Christianorum, Series Latina 73 , Brepols, Turnhout.

Hieronymus, 1964, 'Commentary on Ezekiel', in F. Glorie (ed.), Hieronymi Commentariorum in Ezechielem libri XIV, p. 178, Brepols, Turnhout. (Corpus Christianorum, Series Latina 75)

Hieronymus, 1969, 'Commentary on Micah', in M. Adriaen (ed.), Hieronym Commentarii in prophetas minores, p. 513, Brepols, Turnhout. (Corpus Christianorum, Series Latina 76)

Hippolytus, 1916, 'Refutatio 9, 13, 3', in P. Wendland (ed.), Hippolytus' Werke, 3. Band, Hippolytus, Refutatio omnium haeresium, p. 251, Hinrichs, Leipzig.

Hirsch, S., 1926, Die Vorstellung von einem weiblichen Pneuma Hagion im Neuen Testament und in der ältesten christlichen Literatur, ein Beitrag zur Lehre vom heiligen Geist, Emil Ebering, Berlin.

Irenaeus Lugdunensis, 1965, 'Adversus Haereses 4, 7, 4', in A. Rousseau (ed.), Irénée de Lyon, Contre les hérésies, Livre IV. Édition critique (...) sous la direction de Adelin Rousseau (...). Tome II: Texte et traduction, Les Éditions du Cerf, Paris, p. 464.

Irenaeus Lugdunensis, 1965, 'Adversus Haereses 20, 1', in A. Rousseau (ed.), Irénée de Lyon, Contre les hérésies, Livre IV. Édition critique (...) sous la direction de Adelin Rousseau (....). Tome II: Texte et traduction, Les Éditions du Cerf, Paris, p. 626.
Klijn, A.F.J., 2003, The Acts of Thomas: Introduction, text, and commentary, 2nd rev. edn., Leiden-Boston, Brill.

Kretschmar, G., 1956, Studien zur frühchristlichen Trinitätstheologie, Mohr, Tübingen.

Luomanen, P., 2012, Recovering Jewish-Christian sects and gospels, Brill, Leiden-Boston.

Makarios/Symeon, 1961, 'Hom. 8,1', in E. Klostermann \& H. Berthold (eds.), Neue Homilien des Makarius/Symeon, p. 37, Akademie-Verlag, Berlin.

Makarios/Symeon, 1961, 'Hom. 16,2', in E. Klostermann \& H. Berthold (eds.), Neue Homilien des Makarius/Symeon, pp. 79-81, Akademie-Verlag, Berlin,.

Makarios/Symeon, 1961, 'Hom. 27,1', in E. Klostermann \& H. Berthold (eds.), Neue Homilien des Makarius/Symeon, p. 151, Akademie-Verlag, Berlin.

Makarios/Symeon, 1961, 'Hom. 27,4', in E. Klostermann \& H. Berthold (eds.), Neue Homilien des Makarius/Symeon, p. 155, Akademie-Verlag, Berlin.

Makarios/Symeon, 1964, 'Hom. 16,8', in H. Dörries, E. Klostermann \& M. Kroeger (eds.), Die 50 geistlichen Homilien des Makarios, p. 163, Akademie-Verlag, Berlin.

Makarios/Symeon, 1964, 'Hom. 28,4', in H. Dörries, E. Klostermann \& M. Kroeger (eds.), Die 50 geistlichen Homilien des Makarios, pp. 232-233, Akademie-Verlag, Berlin.

Makarios/Symeon, 1964, 'Hom. 30,2', in H. Dörries, E. Klostermann \& M. Kroeger (eds.), Die 50 geistlichen Homilien des Makarios, p. 241, Akademie-Verlag, Berlin.

Melito of Sardis, 1979, 'Frg. 17', in S.G. Hall (ed.), Melito of Sardis, On Pascha and Fragments, pp. 84-85, Texts and translations by Stuart George Hall, Clarendon Press, Oxford.

Murray, R., 1975, Symbols of church and kingdom. A study in early Syriac tradition, Cambridge University Press, Cambridge.

Odae Solomonis, 2009, '36, 3a', in M. Lattke (ed.), Odes of Solomon, A Commentary by Michael Lattke, transl. M. Ehrhardt, H.W. Attridge (ed.), Fortress Press, Minneapolis, p. 492

Origenes, 1901, 'Homilies on Jeremiah', in E. Klostermann (ed.), Origenes Werke, 3. Band, Jeremiahomilien, Klageliedkommentar, Erklärung der Samuel- und Königsbücher, p. 128, Hinrichs, Leipzig.

Origenes, 1903, 'Commentary on the Gospel of John', in E. Preuschen (ed.), Origenes Werke, 4. Band, Der Johanneskommentar, p. 67, Hinrichs, Leipzig.

Osiek, C., 1999, Shepherd of Hermas, Fortress, Minneapolis.

Outler, A.C. (ed.), 1964 (paperback ed. 1980), John Wesley, Oxford University Press, New York.

Pastor Hermae, 1998, 'Similitudes', in U.H.J. Körtner \& M. Leutzsch (eds.) Papiasfragmente: Hirt des Hermas, pp. 242-359, Eingeleitet, herausgegeben, übertragen und erläutert von Ulrich H.J. Körtner und Martin Leutzsch, Wissenschaftliche Buchgesellschaft, Darmstadt.

Pastor Hermae, 1998, 'Visions', in U.H.J. Körtner \& M. Leutzsch, (eds.) Papiasfragmente: Hirt des Hermas, p. 146-191f, Eingeleitet, herausgegeben, übertragen und erläutert von Ulrich H.J. Körtner und Martin Leutzsch, Wissenschaftliche Buchgesellschaft, Darmstadt.

Pseudo-Clementines, 1969, 'Hom. 16, 12, 1', in B. Rehm (ed.), Die Pseudoklementinen I, Homilien, p. 223, Zum Druck besorgt von Johannes Irmscher. Zweite, verbesserte Auflage besorgt von Franz Paschke, Akademie Verlag, Berlin.

Quispel, G., 2008, 'The Holy Spirit as Woman in Apocalypse 12', in J. van Oort (ed.), Gnostica, Judaica, Catholica: Collected essays of Gilles Quispel, Brill, LeidenBoston.

Robinson, J.M., 2014, The Nag Hammadi story, vol. 1-2, Brill, Leiden-Boston.

Schüssler Fiorenza, E., 1983, In memory of her: A feminist theological reconstruction of Christian origins, SCM Press, London.

Seeberg, R., 1922, Dogmengeschichte, vol. 1, Deichert, Leipzig \& Erlangen.

Seeberg, R., 1924, Christliche Dogmatik, vol. 1, Deichert, Leipzig \& Erlangen.

Schäfer, P., 2002 (paperback 2004), Mirror of his beauty: Feminine images of God from the Bible to the early Kabbalah, Princeton University Press, Princeton.

Theophilus Antiochenus, 1970, 'Ad Autolycum 1, 7', in R. M. Grant (ed.), Theophilus of Antioch, ad Autolycum, p. 10, Text and translation by Robert M. Grant, Clarendon Press, Oxford.

Theophilus Antiochenus, 1970, 'Ad Autolycum 2, 15', in R. M. Grant (ed.), Theophilus of Antioch, ad Autolycum, p. 52, Text and translation by Robert M. Grant, Clarendon Press, Oxford

Thomae Evangelium, 1998, 'Logion 101', in The Gospel according to Thomas, Coptic Text established and translated by A. Guillaumont, H.-Ch. Puech, G. Quispel, W. Till and †Yassah 'Abd al Masīh, Brill, Leiden-Boston-Köln.

Thomae Evangelium, 2014, 'Logion 101', in P. Nagel (ed.), Codex apocryphus gnosticus Novi Testamenti, p. 152, Band 1, Mohr, Tübingen.

Van de Bank, J.H., 1977, Macarius en zijn invloed in de Nederlanden, Rodopi, Amsterdam.

Van Oort, J., 2011, 'The Holy Spirit and the early church: Doctrine \& confession' HTS Theologiese Studies 67(3), Art. \#1120, 8 pages. http://dx.doi.org/10.4102/ hts.v67i3.1120

Van Oort, J., 2012, 'The Holy Spirit and the early church: The experience of the spirit', HTS Teologiese Studies 68(1), \#Art. 1154, 7 pages. http://dx.doi.org/10.4102/hts. v68i1.1154 